\title{
18 Mayıs 1944 Sürgününden Günümüze Kırım Tatarcasının Durumu
}

Işılay IŞIKTAŞ SAVA'

\begin{abstract}
$\ddot{\mathbf{O z}}$
Kırım Tatarcası, Kıpçak Türkçesinin bir koludur ve Kırım Hanlı̆̆ı zamanında teşekkül edip parlak bir dönem yaşamıştır. Kırım Tatar Edebiyatı, 1783 yılında Rus Çarlığı tarafından işgal edilmesiyle 100 yll süren karanlık bir dönem yaşamıştır. İsmail Gaspıralı’nın 22 Nisan 1883’te “Tercüman” gazetesini çıkartmasıyla bu karanlık dönem aydınlanmaya başlamış, 1905’ten sonra canlanmıştır. Ancak, 1917 Bolşevik İhtilâli ve 18 Mayıs 1944 sürgünüyle neredeyse yok olma seviyesine gelmiştir. 1950'li yıllardan sonra Mustafa Abdülcemil Kırımoğlu'nun liderliğinde millî mücadelenin başlaması, 1 Mayıs 1957 tarihinde Taşkent'te Kırım Tatarcasıyla “Lenin Bayrağı” gazetesinin çıkarılması, 1968'de Nizami adına Taşkent Pedoloji Enstitüsü'nde Kırım Tatar Edebiyatı Bölümü'nün açılması, aynı yıl Gafur Gulam Neşriyatı bünyesinde Kırım Tatar yayınları bölümünün kurulması ve Kırım Tatarcası ile yılda 13-14 kitap neşredilmesi, 1976 yılında yılda iki kez Kırım Tatarcasıyla "Yıldız" almanağı yayınlanması ve bu almanağın 1980'de iki ayda bir çıarılan "Yıldız" dergisine dönüştürülmesi, 80’lerin sonlarında Vatan Kırım'a dönülmesi, burada yeniden milli kimliğin inşa edilmeye çalışılması, Kırım Tatarcasının da kaderini etkilemiştir. Fakat ne yazık ki, Şubat 2014’te Kırım, Rusya tarafından tekrar işgal edilmiş, Kırım Tatarları çeşitli baskılara ve zulme maruz kalmıştır. Kırım'da Kırım Tatarca yayın yapan radyo ve televizyonlar kapatılmış, anadille eğitim veren sınıfların sayısı düşürülmüștür. Bu çalıșmada Kırım Tatarlarının ve Kırım Tatarcasının bugüne kadarki tarihî seyrinin ışı̆̆ında Kırım Tatarcasının sürgünden sonraki durumu hakkında bilgiler, eğitim, basın yayın, edebî neşriyat ve sosyolinguistik bakımından incelenecektir.
\end{abstract}

Anahtar kelimeler: Kırım Tatar, Kırım Tatarcası, 18 Mayıs 1944 sürgünü.

\section{The Situation of Crimean Tatar Since The Deportation of May 18 th 1944}

\begin{abstract}
Crimean Tatar is a branch of Kipchak dialects of Turkic languages. It was formed and enjoyed its golden age during the reign of Crimean Khanate. It had the darkest days starting with the Russian invasion in 1783. This dark period ended when İsmail Gaspıralı published the newspaper Tercüman in April 22nd 1883. However the Bolshevik revolution in 1917 and the deportation in 1944 brought Crimean Tatar language to the verge of extinction. After that many events shaping the future of Crimean Tatar occured such as the newspaper Lenin Bayrağ (first published in May 1st 1957), foundation of Crimean Tatar Literature Department in Tashkent Pedagogy Institute, foundation of Crimean Tatar publications department at Gafur Gulam which published 13-14 books each year, publishing of Ylldız Almanac which became a bi-monthly journal in 1980, returning to the homeland Crimea and reshaping of the Crimean Tatar national identity in late 80s. After the Russian invasion in February 2014, Crimean Tatars suffered another oppression period. TV stations and radio channels in Crimean Tatar were shut down and the number of classes teaching Crimean Tatar were reduced.
\end{abstract}

Dr., Ankara Hacı Bayram Veli Üniversitesi, Edebiyat Fakültesi, Türk Dili ve Edebiyatı Bölümü, isilaysava@yahoo.com [Makale kayıt tarihi: 4.8.2018-kabul tarihi: 15.8.2018] 
Using this historical background, this study presents the situation of Crimean Tatar language after the deportation based on education, media, publishing and sociolinguistic aspects.

Key word: Crimean Tatar, Crimean Tatar language, 18 May 1944 deportation.

\title{
Giriş
}

Tarihî seyir içerisinde Altın Orda devletinin dă̆glma döneminde Kırım Tatarları tarafından IV. yüzyılın başlarında müstakil Kırım Hanlığı kurulur ancak 1783’te Çarlık Rusyası tarafından işgale uğrar. 1917 ihtilâli sonrasında Numan Çelebi Cihan'ın başkanlığında Kırım Halk Cumhuriyeti ilân edilir. Hemen kısa bir süre sonra Sovyetler Birliği tarafından bu Cumhuriyet ortadan kaldırılır ve Kırım Tatarları hürriyetlerini kaybederler. 3o'lu yılların başlarında, Sovyetler Birliği’nde Stalin’in yürüttüğü, rejimin mualiflerini ve dönemin aydınlarını ortadan kaldırma planı Kırım’ı da vurur.

1931-1936 yılları arasında Kırım'daki "sovyetleştirme" siyasetiyle müslüman din adamlarının çoğu Kırım'dan sürülür ve öldürülür, cami ve medreseler kapatılır. Kırım Tatar aydınları "burjuva milliyetçiliği” ile suçlanarak takibata uğrar. 1937-1938 yıllarında ise, Stalin hükümetinin uyguladığı yıldırma politikaları neticesinde Kırım Tatarlarının bütün sosyal tabakaları tevkif, sürgün ve imha edilir. Kırım'da Sovyet hakimiyetinin 1921-1941 yılları arasında 160-170 bin Kırım Tatarı öldürülür. II. Dünya Savaşı sırasında 1941-1944 yılları arasında Kırım, Alman ordusunun işgaline uğrar. Sovyet ordusu10-25 Nisan 1944 tarihlerinde Kırım'a girer. Stalin yönetimi, aralarında Kızll Ordu'da savaşan Sovyet kahramanlarının da bulunduğu Kırım Tatarlarını Almanlarla işbirliği yaptıkları bahanesiyle "vatan haini” ilân eder ve Kırım'da bir terör havası estirerek tarihin en büyük katliamlarından birini başlatır. Bu katliamlar Kırım Tatarlarının, 18 Mayıs 1944 gecesi Kırım'dan topyekûn sürgün edilmesiyle sonuçlanır (Kırımal:1970).

Sürgün gecesi Kırım Tatarlarının evleri basılır. Kırım Tatarları, yük vagonlarına üst üste istif edilerek bindirilirler ve Özbekistan’a sürgün edilirler. Yaklaşı 15 gün süren yolculuk sırasında binlerce insan havasızlıktan, açlıktan, hastalıktan vd. bazı sebeplerden hayatını kaybeder. Ölenlerin cesetlerini gömmelerine dahi izin verilmez (Özcan 2007: 27). Kırım Tatarlarının sürgünü hem kurbanlar tarafından hem de sürgünü uygulayanlarca dile getirilmiştir. Benzer şekilde Ann Sheer, 1968 ve 1969 tarihlerinde yazdığı "Kırım Tatarlarının Rus Dostlarından Açık Mektup" ta şunları dile getirir:

\begin{abstract}
“Ateş edilmeyecekti. Seyyar gaz odaları gibi insanlarla dolu hayvan vagonlarında yapılan ölümün hep yanıbaşlarında olduğu bir yolculuk oldu. Yolculuk üç dört hafta sürdü ve onları Kazakistan'ın sıcaktan kavrulan yaz bozkırından geçirdi. Kırım'ın Kızıl çetecilerini, Bolşevik yeraltı savaşçılarını, faal Sovyet ve parti mensuplarını da sürmüsslerdi. Sakatları ve ihtiyarları da. Geriye kalan erkekler cephede faşistlere karşı çarpışıyorlardı, fakat harbin sonunda onları da sürgün bekliyordu. Bu esnada onların kadınları ve çocuklarını -ki çoğunluğu bunlar teşkil ediyorlardı, vagonlara doldurulmuşlardı. Ölüm, yaşlıları, küçükleri ve zayıfları biçiyordu. Susuzluktan, havasızlıktan ve pis kokudan ölüyorlardı... Uzun molalarda cesetler hemen vagonların yanı başlarında gömülüyorlardı, yiyecek ve su dağıtılan kısa molalarda ise ölülerini gömmeye müsaade etmiyorlar ve demiryolu raylarının yanına bıraktırıyorlardı (Fisher, 2009: 237).
\end{abstract}

Sürgün sona erdikten sonra bile halkın toptan imhasına devam edilmiştir. Hükümet makamlarının mahallî halk arasında yaptıkları propagandadan dolayı Tatarlar düşmanca karşılanmışlardır. Sıcağa, sıtmaya ve her şeyden önce Kırım'dakinden daha az temiz olan suya alışık olmayan Tatarlar hastalanmışlar, zayıf düşmüşler ve ne yazık ki çoğu da hayatını kaybetmiş̧lerdi (Fisher, 2009). Oldukça ağır şartlar altında geçen sürgünün ilk yllında 112.700 çocuktan 60.034'ü, 93.200 kadından 40.085'i, 32.600 erkekten 12.061'i bu dünyadan göç etmiştir. Bu, sürgün edilen halkın \%46.2'sidir ve diğer bir 
deyişle halkın neredeyse yarısı demektir. Sürgünden sonra sürgün yerlerindeki aileler arasından elde edilen bilgilerde sürgün edilen 423 bin Kırım Tatarının \% 46'sı hayatını kaybettiği tespit edilmiştir (Özcan, 2007:38).

Yarımadadan Kırım Tatar varlı̆̆ını tamamen silmeye kararlı olan Sovyet yönetimi, buradaki Türk kültürünün izlerini de ortadan kaldırmak istemişti ve bu maksatla ilk olarak Kırım'daki Kırım Tatarca bütün yer adlarını Rusça isimlerle değiştirmiştir. Ardından da Lenin tarafından 1921'de "doğunun meşalesi” olması gayesiyle kurulan Kırım Özerk SSC, 30 Temmuz 1945'te ortadan kaldırılarak Rusya Federasyonuna bağlı Kırım bölgesine çevrilmiştir. Stalin’in ölümünün ardından Hruşçev’in iktidarında, Kırım Ukrayna'nın Rusya'ya bağlanışının 30o. yıldönümünde Ukrayna SSC’ne 19 Şubat 1954'te hediye edilmiştir. Tam o zamanda Kırım'da bir tane bile Kırım Tatarı kalmamıştır. Kırım'daki Türk varlığının izlerinin silinmesi için yöneticiler ve yerel halk tarafından evler yıkılmış, bağlar ve bahçeler kullanılmaz hâle getirilmiştir. Tatarlara ait mezarlıklar sürülmüss, mezarlıktaki cesetler "dirilerin çektikleri ıstırapları çeksinler” diye mezarlarından çıkarılmış, mezar taşları sökülüp inşaat malzemesi olarak kullanılmıştır. Marksist-Leninist eserler dahil olmak üzere Kırım Tatarcası ile yazılan binlerce kitap yakılmıştır.

Kırım Tatarları vatanlarından uzak yerlerde, vatan Kırım’a dönebilmek için türlü zorluklara göğüs germişler; baskı ve zulümlere karşı var güçleriyle mücadele etmişlerdir. Onların bu mücadelesi özellikle 1960'ların ikinci yarısından sonra sürgün günü 18 Mayıs'ın ve Kırım Muhtar Sovyet Sosyalist Cumhuriyeti’nin kuruluş günü olan 18 Ekim'in yıldönümlerinde düzenledikleri geniş kitlelerin katılımıyla gerçekleşen mitinglerle, gösterilerle artmıştır. Ayrıca Kırım Tatarları seslerini dünyaya duyurabilmek için Moskova'daki insan hakları savunucularıyla irtibata geçmişlerdir. Sovyet Hükûmeti, 5 Eylül 1967'de bir kararname yayımlayarak Kırım Tatarlarına haksızlık yaptığını kabul eder; ama Kırım Tatarlarının vatan Kırım’a dönmelerine izin vermez. Yani suçun işlenmediği kabul edilir ama suça verilen ceza kaldırılmaz. Her türlü baskıya rağmen 1970'li yıllarda Kırım Tatarlarının millî mücadeleleri Mustafa Abdülcemil Kırımoğlu’nun liderliğinde devam etmiştir. Özellikle Kırımoğlu'nun 303 gün süren açlık grevi, dünya basınının dikkatini ve ilgisini Kırım Tatarlarının üzerine çekmiş; Sovyet bilim adamlarının da destek vermesi bu mücadeleyi güçlendirmiştir (Kırımoğlu: 2004).

Daha önce Sovyet İdaresi, Kırım Tatarlarının vatan Kırım'a dönmelerine her türlü engeli çıkarırken 1980'li ylllarda Rusya'da değişim rüzgârlarının esmesiyle 1987 yılında Moskova'da Kızıl Meydan'da iki bine yakın Kırım Tatarının başlattığı protesto gösterileri olumlu sonuçlanır ve Kırım Tatarlarının şartlı da olsa Kırım’a dönmelerine izin verilir. Özel bir tüzüğü ve faaliyet programı olan Kırım Tatar Millî Hareketi Teşkilatı 2 Mayıs 1989'da kurulur ve bu teşkilatın başına Mustafa Abdülcemil Kırımoğlu seçilir. Kırım Tatar Millî Hareketi Teşkilatı, kurulduğu andan itibaren çadır şehirler kurar ve Kırım’a geriye dönüşleri hızlandırır. SSCB’nin dağılmasından önce Moskova'nın emriyle Kırım’ı SSCB'nin Muhtar Sovyet Sosyalist Cumhuriyeti ve Birlik Antlaşması'nın iştirakçisi statüsüne getirmek amacıyla 20 Ocak 1991'de bir referandum düzenlendi. "Evet” ile sonuçlanan referandum Kırım Tatarlarının itirazlarına rağmen Ukrayna Yüksek Sovyeti tarafından onaylandı ve 12 Şubat 1991'de Kırım Özerk Cumhuriyeti kuruldu. Sürgünün 50. yıldönümünde 1994'te Ukrayna ve Kırım'daki resmî otoriteler “18 Mayıs'ı” resmen matem günü ilân ederek Tatarlara haksızlık yapıldığını kabul etmiş oldu. Kırım Tatarlarının vatana dönüş mücadelesi uzun ve çok zorlu olmuş, Kırım Tatarları dönünce başka meselelerle de mücadele etmek zorunda kalmışlardır. İşsizlik, yerleşme sıkıntıları, çeşitli din adamlarının misyonerlik faaliyetleri, eğitimle ilgili meseleler gibi. Bugün sürgünden sonra hayatta kalabilen ve vatan Kırım'a dönebilme başarısını gösteren yaklaşık 300.00o Kırım Tatarı, çadır kentlerde yaşamakta, millî ve kültürel kimliklerini koruyup yaşatmaya çalışmakta, sosyo-ekonomik meselelere göğüs gererek hayatlarını sürdürmekte idi (Kırımoğlu, 2004 : 231-232, Aydıngün, 2004: 79-94) 
27 Şubat 2014'te Moskova (Rusya), Kırım'da bir darbe organize etti, kendisine bağlı yerel hükümeti başa geçirdi ve Kırım'ın siyasî geleceği konusunda bir referandum ilân etti. Referandum, kurallara uymuyordu ve meşruiyetten uzaktı. 293 yerli ve yabancı akademisyenin açı mektuplarında belirttikleri gibi Rusya’ya katılmaya \%97 onay veren referandumun sonucu sahte idi. Kırım Tatar Kurultayı ve Kırım Tatar Millî Meclisi referandumu tanımadığını açıkladı, Kırım’ın Rusya tarafından işgaline ve ilhakına kesinlikle karşı çıktı. Bunu müteakip zaman içinde 20 Kırım Tatar erkeği kaçırıldı veya ölü bulundu. Reşat Ametov, işgale karşı kent meydanında tek kişilik sessiz bir protesto yürütmesinin ardından kaçırıldı ve ölü bulundu. Kırım Başsavcısı "her kim işgali tanımazsa Kırım’dan sürülecektir" şeklinde açıklama yaptı. Rusya’nın istihbarat servisi FSB, Kırım Tatar Millî Meclisi’ni işgal etti, bilgisayarlarına, belgelerine ve paralarına el koydu (Şamilkızı: 2017)

Yukarıda belirttiğimiz tarihî hadiseleri ve Kırım Tatarcasının kullanım alanlarını göz önünde bulundurarak şu başlıklarda değerlendirebiliriz:

\section{Sürgün Yıllarında (1944-1989) Kırım Tatarcasının Durumu}

1944'ten 1957'e kadar hayatla bağları koparılan; kültürleri, millî benlikleri unutturulmaya çalışllan, vatan Kırım'ın adının kullanılması bile suç sayılan Kırım Tatarları için 1957 yılı biraz da olsa umut kapısının aralandı̆̆ı yıl olur. 1 Mayıs 1957'den itibaren Taşkent'te Kırım Tatarca “Lenin Bayră̆ı” gazetesi çıkmaya başlar, sonradan "Kaytarma" adını alan Kırım Tatar oyun ve yır topluluğu teşkil edilir. Aynı yıl, Özbekistan yazarlar birliği yanında Kırım Tatar Edebiyatı bölümü meydana getirilir ve o bölüm kendi etrafına, felâketli yıllardan să̆ kalan edipleri toplar (Fazıl 2001: 406). Bu gelişmelerin ardından Taşkent’te bulunan Gafur Gulam neşriyatının içinde Kırım Tatar Edebiyatı Bölümü’nün açılmasıyla birlikte Kırım Tatarcasıyla yılda 13-14 kitap basılır. 1976'da ise yılda iki kez Kırım Tatarcasıyla "Yıldız" almanağı çıkarılmaya başlanır ve bu almanak 1980'de iki ayda bir çıkan "Yıldız" adlı edebî ve içtimaîsiyasî dergiye dönüştürülür (Fazll 2001: 407-410).

Leniyara Celilova Kırım Tatar Millî Matbuat Tarihî adlı eserinde o yıllarda çıkan gazete ve dergileri şöyle değerlendirir: "Bu gazete ve dergilerin içeriği halkın hür tefekkürünü yansıtmıyordu. Yayınlar sadece Kırım Tatarca yayımlanan Sovyetler Birliği'nden haberler niteliğindeydi. Kırım Tatar halkı, kültürü, dili ve halk edebiyatı ile ilgili makaleler dördüncü sayfada yayımlanıyordu.” (2017:61).

Dönemin gazete ve dergileri şu şekildedir:

\section{Gazeteler}

\subsection{Lenin Bayrağı}

1944'ten sonra Sovyetler Birliği'nde çıkan Kırım Tatarca ilk gazetedir. 1 Mayıs 1957'de yayın hayatına başlar. Önceleri haftada iki kez, sonra üç kez 4 sayfa olarak yayınlanır. Neşir hayatının ilk 20 yılında (1957-1978), “Kırım”, “Kırım Tatarları”, “Kırım Tatarcası” gibi sözler kullanılmaz. Daha sonra 1988’e kadar ise bu sözleri ihtiyatlı bir şekilde gazetede yer alır. Gazete Özbekistan Sovyet Sosyalist Cumhuriyeti’nin yayın organı olduğu için politik hadiseleri, bazı propagandaları ve siyasî liderlerin nutukları dönemin şartları gereği yayımlanmakta bir yandan da bazı sayılarında Kırım Tatarca sözlük kısmı koyarak Kırım Tatarcaya katkı sağlamaktaydı. Gazete 1988 yılına kadar yayın hayatına devam etmiştir (Celilova 2017: 62).

\subsection{Semizdat}


Semizdat, devlet sansürü tarafından neşri ve serbest dağıtılması yasaklanan el yazma veya basılı malzemedir. Kırım Tatarları, Semizdat'ı Rusça yayımlamıştır ve Kırım Tatarlarının tarihi, onlara uygulanan haksızlıklar yer almaktaydı. Batılı ülkelere 1960'lı yılların ikinci yarısında Kırım Tatar Semizdatları ulaşır ve bunlar Kırım Tatar Millî hareketine fayda sağlar. (Celilova, 2017:62-63)

\subsection{Baharistan Akiqatı, Tañ, Dostluq Bayrağı Gazeteleri}

Özbekistan'ın uzak ve az nüfuslu yerlerinde yaşayıp vatan Kırım'a dönmeye çalışan Kırım Tatarları için Sovyet idaresi tarafından 1985 yılında çıkarılan gazetelerdir. Kısa zaman içinde kapanmıştır (Celilova, 2017:66).

\section{Dergiler}

\subsection{Yıldız}

Taşkent’te 1976 yılında Yıldız almanağı olarak çıkmaya başlar ve 1980’e kadar yılda iki kere, 1980'den itibaren de siyasî, içtimaî ve bediî dergi olarak iki ayda bir kere 4-5 bin tirajlar yayımlanır. Dergi nesir (Kırım Tatarca yeni roman, hikâye, uzun hikâye gibi edebî türler ve Tatar yazarlar hakkında bilgiler), nazım örnekleri, tarih, felsefe, dilcilik, edebiyat incelemeleri, kitap tanıtma gibi çeşitli bölümlerden oluşmaktaydı (Celilova, 2017: 65). Dergi Kırım Tatarlarının vatan Kırım’a dönüşünden sonra da yayına devam etmiştir.

\subsection{Sooteçestvennik (izgnannik)}

1989 Ocak ayında Özbekistan’ın Yengiyol şehrinde aylık olarak çıkan bir bültendir (Celilova, 2017:66).

\subsection{Qasavet}

1984 yllında Taşkent'te iki sayı, 1985 'te her iki ayda bir, 1986'da ise yalnız üç sayı çıar. Önceleri edebî aktüel, sonra sosyal politik, 1987'den itibaren tarihî etnografik, ibareleriyle çıkar. Dergi 1988, 1989 ve 1991 yıllarında Litvanya'nın Vilnius şehrinde çıkar. 1990'dan sonra dergi ilmî dergiye dönüşür (Celilova, 2017:67).

\section{Vatan Kırım'a Dönüş Sonrası (1989-2014) Kırım Tatarcasının Durumu}

\subsection{Eğitim ve Ana Dil}

26 Haziran 1991 tarihinde Akmescit’te Kırım Tatar Millî Kurultay'ı toplanır ve Kırım Tatar halkının en yüksek temsil organı olmak üzere Kırım Tatar Meclisi teşkil edilir. Kırım'da Kırım Tatarlarının her türlü problemini çözmek için komiteler kurulur, faaliyete geçilir (Kırımoğlu, 2007: 29-30).

Kırım Tatarlarının vatanlarına, Kırım’a döndükten sonra karşılaştıkları işsizlik ve barınma sıkıntılarının ardından mücadele edecekleri en büyük problemlerin başında eğitim gelir. Eğitim sıkıntısı Sovyet dönemi boyunca sürmüş, Kırım Tatar çocukları kendi dilleriyle eğitim alamamışlardır. Vatana dönünce dil problemini bir sadece ana dille eğitim sınırlarında değil, aynı zamanda kültürel bir mesele olarak ele almışlardır. Bu düşüncelerle Millî Mekteplerin açılması süreci başlamıştır. Bir süre sonra sayıları 10’u bulan bu mekteplerin şartlarının iyi olmaması ve yeniliği, ana dille verilen derslerin saatlerinin az olması, ana dilde materyal eksikliği, önlerine çıkan bazı yasal engeller, bazı Tatar çocuklarının velilerini 
Rus mekteplerine yönlendirmiştir Millî Mektepler’in haricinde yüksek öğrenim için de Kırım Devlet Sanayi ve Pedoloji Enstitüsü’nde Türk Dili ve Edebiyatı Bölümü açılmıştır. Daha sonra bu enstitü, Kırım Devlet Mühendislik ve Pedoloji Üniversitesi adını almıştır. (Aydıngün 2004: 94-101).

\title{
4.2. Matbuat
}

1989'dan sonra Kırım'da yayımlanmaya başlanan ilk Kırım Tatarca süreli yayınlar, maddî imkânsızlıklar sebebiyle mahallî Rus gazetelerinin içinde Tatarca ayrı bir ek şeklinde küçük ebatlarda çıar. 1991'den itibaren müstakil şekilde süreli yayınlar çıkmaya başlar ve 1993’ten sonra da sayıları artar.

\subsection{Gazeteler}

\subsubsection{Dostluk Gazetesi}

$\mathrm{Bu}$ gazete, Kırım Tatarlarının vatanlarına dönmeleriyle, sürgünden 45 yıl sonra Kırım’da Kırım Tatarcasıyla yayımlanan ilk gazetedir. 7 Temmuz 1989'da Akmescit'te yayın hayatına başlar ve Kırımskaya Pravda gazetesinin içinde cuma günleri haftalık olarak çıkar. Muhtevası Kırım Tatarlarının millî meseleleridir. 1995'ten itibaren müstakil bir gazete olarak ve Kırmm adıyla yayımlanır (Celilova, 2017:70). Mehmet Ali Yolcu, gazetenin içeriği ile ilgili şunları dile getirir:

\begin{abstract}
"Milliy Medeniyet", "Milliy Tasil", “İlmiy Tasil", "Milliy Tarih", "İslam Nurı" ve "Tilge İtibar-İlge İtibar" başlıkları altında Kırım Tatarlarının diline, kültürüne, tarihine, geleneksel hayatına, dini ve milli bayramlarına dair yazllara ve haberlere de yer veren gazetede Kırım Tatar milli kimliğinin temel taşlarından folklor ürünlerine de sıklıkla rastlanmaktadır. "Kırım (Qırım)" gazetesinde Kırım Tatar halk yırları, çın ve maneleri (manileri), türküleri, ninnileri, tekerlemeleri, sayışmacaları, atasözü ve deyimleri, destanları (Çora Batır), halk masalları, efsane ve rivayetleri, fikraları (Nasreddin Hoca, Ahmed Ahay) ile halk adet ve gelenekleri hakkında çok sayıda yazı yer almıştır. Yazıların büyük bir çoğunluğu Kırım Tatar halk edebiyatı örneklerini içermekle birlikte, Kırım Tatar folklorunun Kırım Tatar çocukları ile gençlerinin yetiştirilmesindeki rolü üzerine odaklanan bazı önemli yazılara da yer verildiği görülmektedir. Gazetede yer alan yazılarda atasözleri ile deyimlere özel bir yer ayrılmıştır (2015:118).
\end{abstract}

\subsubsection{Yañı Dünya Gazetesi}

Kırım Tatarlarının büyük kısmının Kırım’a dönmesiyle okuyucu kaybeden Lenin Bayrağı gazetesi 1989 yılında Taşkent'te ayda bir çıkıyordu. Gazetenin yazı kurulu Kırım'a gelince 1991'de Yañı Dünya gazetesi doğar. Haftalık olarak Kırım Tatarcasıyla çıkmaktadır (Celilova, 2017:70). Muhteva bakımından Kırım Tatarlarının siyasî, dinî, içtimaî hayatı ile birlikte örf-adetleri ve Kırım Tatar edebiyatı, sanatı hakkında bilgileri içermektedir. Gazetede Kırım Tatar örf ve âdetlerine, atasözü ve deyimlerine, bilmecelerine, ninnilerine, tekerleme ve sayışmacalarına, rüya tabirlerine, efsane ve rivayetlerine, dinî ve millî bayramlara özel bir önem verildiği göze çarpmaktadır. Ayrıca yer verdiği bu tür yazılarla daha çok Kırım Tatar çocukları ile gençlerine yöneldiği gözlemlenen "Yañı Dünya" gazetesi, Kırım Tatar gençlerinin Kırım Tatar geleneklerine ve sözlü kültürüne olan ilgilerinin artmasında hatırı sayılır bir rol üstlenmektedir, denebilir.

\subsubsection{Avdet Gazetesi}

15 Temmuz 1990'da yayın hayatına başlayan gazete, ilk yllarında Rusça son zamanlarda ise Kırım Tatarca ve Rusça olarak çıkmaktadır. Haber ve yazılarına "cemiyet", "medeniyet” (kültür), "siyaset", "tarih", "şahıslar" ve "vaqigalar" (olaylar) başlıkları altında yer veren gazete, Kırım Tatar halk bilimi ürünlerine de yer vermiştir. Bunlar arasında "latifeler" (Ahmet Ahay, Nasreddin Hoca latifeleri), "ma- 
sallar”, "rivayetler”, “ninniler”, “atasözü ve deyimler”, "halk yırları”, “destan” (Qırımnıñ Qırq Batırı), "geleneksel bayramlar" (Navrez, Hıdırlez) ve "halk müziği” yer almaktadır (Celilova, 2017:73-74, Yolcu 2015: 318).

Bu gazetelerin haricinde Kırım'da Közyaşı, Meraba, Qırım Sadası (Türkçe ve Latin harfli), Salğır, Maalle (Rusça), Golos Qırıma (Rusça), Tilde Birlik (Latin harfli Kırım Tatarca), Hidayet (Kiril Harfli Kırım Tatarca, dinî), Suvdağ Sesi, Edebiyat ve Sanat, İnitsium (hukuk, Rusça), Maarif İşleri (Kırım Tatarca), Balalar Dünyası, Yurt, Eski Yurt, Sarabuz, Zaman, Aztlıq (Rusça), Qasaba (Kiril-Latin Kırım Tatarca) gibi gazeteler de yayın hayatında yer almıştır.(Celilova:2017)

\subsection{Dergiler}

\subsubsection{Tañ Dergisi}

2004’ten beri Akmescit’te çıkmaktadır. Aylık dergidir, Kırım Tatarcasıyla çıkmaktadır.

\subsubsection{Nesil Dergisi}

2009'dan beri Kırım Tatarcasıyla çıkmaktadır.

\subsubsection{Alem-i Nisvan-Arz1}

2009'dan beri Kırım Tatarcasıyla yayın yapmaktadır.

\subsubsection{Nenkecan}

3 Mart 2011'de Kırım Tatarcasıyla çlkmaya başlar.

Bu dergilerin haricinde Salğır, Vatan, Yıldızçıq, Ha ha ha dergileri de yayınlanmıştır (Celilova:2017).

\subsection{Kitaplar}

1989'dan sonra Kırım'da kitap basımı da zaman içerisinde artmıştır. Basılan kitaplar arasında sözlükler, roman ve hikâyeler, inceleme ve derleme kitapları gibi farklı türler de bulunmaktadır. Bunlardan bazılarına örnekler aşağıda yer almaktadır (Yolcu 2015:121-126):

Üseinov, S.M. (2008), Qırımtatarca-Rusça-Ukraince Luğat, Aqmescit, “Tezis” Neşriyat evi

Üseinov, S.M. (2005), Qırımtatarca-Rusça Luğat, Simferepol (Akmescit) “ Ocaq”

Bekirov, Cafer (1993), Bala Folklorı, Tavriya Neşriyatı, Akmescit

Bahşış, İlyas; Nalbandov, Edem (1996), Kırımtatar Halk Yırları, Tavriya Neşriyatı, Akmescit

Özenbaşlı,E. M., (2000), Aytımlar Lugatı, Simferopol (Akmescit)

Aliyev, F. M., (2001) Antologiya Krımskoy Narodnoy Muzikı, Krımskoe Uçebno-Pedagogiçeskoe Gosudarstvennoe İzdatel'stvo, Simferopol (Akmescit)

Asanov, Şevket (2002), Atalar Sözleri ve Aytımlar: Kırımtatar Tiliniñ Terminologik Lugatı, Kırım Devlet Okuv-Pedagogika Neşriyatı, Simferopol (Akmescit)

Vapiyev, Subhi (2002), Kış Akşamları: Efsane ve Rivayetler, Ocaq, Akmescit

Edemova, Uriye (2004), Kırımtatar Efsaneleri, Tavriya Neşriyatı, Akmescit 
Keriçke Ketseñ, Kazantipke Tiye Ket (Keriç Yarımadası Kırımtatarlarınıñ Atalar Sözleri ve Aytımları), (2004), (Toplă̆an S. Vapiyev-K. Koñguratlı Useinov-F. Cepperova), Ocaq, Simferopol (Äkmescit)

Osmanov, Dilâver.,Karikov, Cemil (2005) Qırımnıñ Çöl Yırları, Simferopol (Akmescit)

Fazıl, Rıza., (2005), Alim-Qırım Yigiti Alim Aqqında Hatırlavlar, İkâyeler, Rivayetler, Qırım Devlet Okuv-Pedagogika Neşriyatı, Simferopol (Akmescit)

Kerim, Yaqub (2006), Küçük Özen Tarih, Etnografiya, Dolya Neşriyatı, Akmescit

Muzafarov, R. İ. (2007), Qırımtatarlarının Atalar Sözleri, Simferopol (Akmescit)

Ümerov, Nüzet (2007), Qırımtatar Halq Masalları ve Efsaneleri, Etnos, Kiyev

Süleymanov, Rüstem (2007), Masallar, Tarpan, Akmescit

Camanaqlı, Kerim., Üseyin, Amet (2008), Qırımtatar Halq Masalları, Qırımdevokuvpedneşr Neşriyatı, Simferopol (Akmescit).

Bekirov, Cafer (2008), Qırımtatar Halq Ağız Yaratıcılığı Hrestomatiya, Kırımdevo-kuvpedneşir, Simferopol (Akmescit)

Kerim, Yaqub (2009), Ulu Özen ve Ulu Özenliler, Etnografiya, Tarih, Kırımdevokuvpedneşir Neşriyatı, Akmescit

Köroğlu: Destan (2009). (İşlegen, tertip etken ve neşirge azırlağan İ. A. Qasumov; Muarrir N. S. Seytagaye), Qırımdevokuvpedneşir, Simferopol (Akmescit)

Canay, Gülser (2009), Qırımnıñ Sönmegen Ateşi, Tezis, Akmescit

Kerim, Yaqub (2011), Quru Özen Zamanlar, İnsanlar, Taqdirler, Qırımdevokuvpedneşir Neş-riyatı, Akmescit

Bekirov, Cafer (2012), Nesillerden Nesillerge Miras, FLP Lemeşko K. A. Neşriyatı, Aqmescit

Muradasılov, Asan (2012), Halq Ağız Yaratıcılığı Rivayetler, Kırımdevokuvpedneşir, Simferopol (Akmescit)

\section{2014'te Rus İşgalinden Sonra Kırım Tatarcasının Durumu}

2014 yılında yeniden Ruslar tarafından işgal edilen Kırım'da Kırım Tatarları için zor günler başlar. İşgalden sonraki 1000 gün içinde işgalci Rusya Federasyonu bu işgali tanımayan Kırım Tatarlarına ve Ukrainlere zulmetmeye devam eder.

-Kırım Tatarlarının Millî lideri Mustafa Abdülcemiloğlu, Kırım Tatar Millî Meclisi ve DQTK Başkanı Refat Çubar, Kırım Tatar Millî Hareketi üyesi Sinaver Qadir, Kırım Haber Ajansı koordinotörü İsmet Yüksel ve daha pek çok Kırım Tatar aktivistinin Kırım'a girişi yasaklandı ve onlar vatanları Kırım'dan sürgün edildi.

-Kırım Tatarlarına ait okullar, camiler, çocuk yuvaları işgalci güçler tarafından basıldı.

-Kırım Tatar (ATR, QHA, Radyo Meydan, Lale vb.) ve Ukrain medya kuruluşları kapatıldı.

-Onlarca gazeteci darp edildi, tutuklandı; 35.00o'den fazla kişi Kırım’ı terk etmek zorunda kaldı.

Günümüzde Kırım'da Kırım Tatarcasıyla yayınlanan sadece 4-5 gazete ve dergi bulunmaktadır. Bunların da ikisi işgal güçleri tarafından yönetilmektedir. Kırım Tatarcasıyla yazılmış belgeler kabul edilmemekte, yarımadada eğitimin \%96.9'u Rusça yapılmaktadır. 2016'da Kırım Tatarca eğitim veren 15 okul olduğu ancak sınıf sayısının işgal öncesine göre düştüğü ve 2013’te 383 iken 2016'da 201 olduğu 
vurgulanmaktadır. Öğrenci sayısının da 2013'te 5551 iken 2016'da 3651 olduğu belirtilmektedir (Şamilkızı 2017: 168-173)

\section{Sonuç}

Kırım Tatarcası, tarihî Kıpçak Türkçesinin bir koludur ve köklü bir geçmişi vardır. Zaman içerisinde tarihî gelişmelerle çeşitli badireler atlatmış, zaman zaman gelişimi sekteye uğramış ve bunlara rağmen hayatta kalmaya çalışmıştır. Konuşur sayısı ve gelecek kuşaklara aktarma gibi etkenleri göz önüne alarak UNESCO tarafından yapılan çalışmada Kırmızı Kitap’ta, Kırım Tatarcası 6 seviyede tespit edilen tehlikedeki diller listesinde 3. seviyede tehlikedeki dil grubunda gösterilmektedir (Sava, 2014: 146-147). Tabii gelişimi ve seyrinin (ölümler, savaş vb.) haricinde konuşurlarının sürgüne uğraması, anadilin kullanımının yasaklanması, eğitimin anadille yapılamaması, ana dille yayımlanan gazete-dergilerin kapatılması, son işgalden sonra Kırım Tatarlarının vatanlarını terk etmek zorunda kalıp başka ülkelere yeniden gitmeleri gibi işgalcilerin sebep olduğu durumlar Kırım Tatarcasına zarar vermektedir.

Kırım Tatarları, tarihin hiçbir döneminde kimliklerinden, millî değerlerinden vazgeçmemiştir ve anadillerini, millî değerlerini korumak için ellerinden geleni yapmıştır. Ne kadar zor durumda olursa olsun bu millî mücadelelerini devam ettirecektir. Kırım Tatarcasını bilen kuşaklar kendinden sonra gelenlere ana dillerini yazılı veya sözlü öğretmeye çabalamaktadır.

\section{Kaynakça}

Aydıngün, Ayşegül., Aydıngün, İsmail. (2004). Kırım Tatarlarının Vatana Dönüşü, Kimlik ve Kültürel Canlanma, Atatürk Kültür Merkezi Başkanlığı Yayınları

Celilova, Leniyara. (2017). Kırım Tatar Millî Matbuatı Tarihi, Akdeniz Titiz Yayınları

Fazıl, R., Nagayev, S. (2001). Qırımtatar Edebiyatınıñ Tarihi. Simferopol: Qırım devlet oquv-pedagogika neşriyatı: 406

Fisher, Alan. (2009). KırımTatarları (Çev. Eşref B. Özbilen), Selenge Yayınları

Kırımal, E. (1970). Kırım Türkleri. Emel İki Aylık Fikir-Kültür Dergisi. s.59 (Temmuz-Ağustos),s.11-15

Kırımoğlu, M.A. (2004). Kırım Tatar Millî Hareketinin Kısa Tarihi (Rusçadan Türkçeye Çeviren : Hakan Kırımlı). Kırım Türkleri Kültür ve Yardımlaşma Derneği Genel Merkezi Yayınları No 6.

Özcan, Kemal. (2007). Sovyet Belgelerinde Kırım Dramı, Kırım Türkleri Kültür ve Yardımlaşma Derneği Genel Merkezi Yayınları: 10, İstanbul Şubesi :3

Sava Işıktaş, Işılay. (2014). Şiirde Ana Dil Vurgusuna Örnek: Şakir Selim'in Şiirlerinde Kırım Tatarcasının Yeri, Gazi Türkiyat, Bahar 2014 /14: 145 -156

Şamilkızı, Gönül. (2017). Kırım Ateşi Bir İşgalin Anatomisi, Ötüken Neşriyat, Yayın Nu: 1276

Yolcu, Mehmet Ali., Aça , Mehmet. (2015). Kırım Tatar Kimliğini Yeniden İnşa Etme Çabalarında Süreli Yayınlar ve Kitaplarda Yer Alan Folklor Ürünlerinin Rolü (1991-2014), Türk Dünyası İncelemeleri Dergisi/Journal of Turkish World Studies 15/1 Yaz-Summer 2015 